\title{
DEBATE
}

\section{Reply to Brassington}

\section{T Szasz}

J Med Ethics 2002;28:124-125

Correspondence to:

Professor T Szasz, 4739

Limberlost Lane, Manlius,

NY 13104-1405, USA;

TSZASZ@aol.com

Accepted for publication 7 November 2001
I thank Brassington for his reply, especially for stating "that there is rather a lot going for Szasz's argument, and I agree broadly with the conclusion". In further support of my thesis regarding the fictitious nature of mental illness as a disease similar to diseases of bodily organs, I add the reminder that, prior to the sixteenth century, the word "mind" meant only minding. The birth of the concept of mind as an entity and of the term "mind" as a noun is the symptom of the metamorphosis of the mediaeval, religious view of the world into the modern, scientific view of it.
$\mathrm{B}$ rassington raises a number of questions, all of which I have answered in some of my books that he might not be familiar with.

1. "Is it the 'mental', the 'illness', or both that don't exist?" Neither exists. In the preface to my book, The Meaning of Mind, I state: "My aim in this book is to present a systematic exploration and exposition of the thesis that minding is the ability to pay attention and adapt to one's environment by using language to communicate with others and oneself. Specifically, I suggest that viewing 'the mind' as a potentially infinite variety of self-conversations is the key that unlocks many of the mysteries we associate with this concept."1 I begin the body of the text as follows:

Today, the word "mind" functions as both noun and verb. It was not always so. Before the sixteenth century-when persons had souls, not minds-the word "mind" meant only minding. The birth of the concept of mind as an entity and of the noun "mind" as its name is the symptom of the metamorphosis of the mediaeval, religious view of the world into the modern, scientific view of it. As a noun, the mind resembles its predecessor, the soul, each naming an unobservable entity. Only in its verbal form-as in "never mind" or "minding the baby" - does the word "mind" have an observable meaning. Because there is no observable entity called the "mind," we identify the concept in terms of certain activities which we attribute to it, foremost among them thinking. ${ }^{2}$

2. "From the tenor of the paper, I think that Szasz's position must be that ... not being an organ, it [the mind] is not the sort of thing that can get ill." Yet, a few pages later, Brassington writes: "Szasz seems to be committed to the possibility of mental health-it is the illness that is phlogiston-but perhaps it is just as mythical as mental 'illness'."

I am committed to no such possibility. Beginning with my 1960 paper, "The Myth of Mental Illness," I have made it clear that both concepts are metaphorical-mythicalmisuses of medical terms in the realm of morals and politics. ${ }^{3}$

3. "[Szasz's] early admission of his 'wish only to maximise the scope of voluntaristic explanations-in other words, to reintroduce freedom, choice, and responsibility into the conceptual framework and vocabulary of psychiatry' is wholly consistent with his latest claim that '[e]rroneous explanations ... lead to ... false expectations of the human condition, to moral catastrophes'. But this demand to bring the psychiatric back into the realm of the moral, which motivates much of Szasz's work, is itself a moral demand, and arguably lacks epistemological or metaphysical backing."

For the sake of keeping the essay focused on medical ethics in general and on coercive psychiatric practices in particular, I wanted to make my argument brief and simple and avoided encumbering it with philosophical complications. I have offered epistemological backing for my argument in several of my books. ${ }^{4}$

4. "Inverting the argument can give pretty much the same result-a moral equivalence of the 'insane' and 'sane' but on the basis not that the 'mentally ill' are no less autonomous than the healthy, but rather that the 'mentally healthy' are no more autonomous than the ill."

This is the familiar biological reductionistic explanation of human behaviour, beloved — at least as lip service-by psychiatrists. In recent decades, the canons of respectable scholarship and respectable journalism alike have virtually mandated that we view only such explanations as scientific. The following statement, by Steven Weinberg-a Nobel laureate and professor of physics at the University of Texas-is typical:

There are no principles of psychology that are free-standing, in the sense that they do not need ultimately to be understood through the study of the human brain, which in turn must ultimately be understood on the basis of physics and chemistry. ... Of course, everything is ultimately quantum-mechanical; the question is whether quantum mechanics will appear directly in the theory of the mind, and not just in the deeper-level theories like chemistry on which the theory of the mind will be based. ... [M] any of our fellow citizens still think that George [a hypothetical actor] behaves the way he does because he has a soul that is governed by laws quite unrelated to those that govern particles or thunderstorms. But let that pass. ${ }^{5}$

I end The Meaning of Mind by quoting this passage and adding: "My aim in this book has been to prevent such reductionism from passing as self-evident". ${ }^{\prime}$ I might add that our inability to conduct our daily affairs as if none of us were responsible for what we do ought to have some force on judging the merit, or demerit, of such philosophising.

5. "Reasons and causes are entirely compatible; one's reason for doing something may be sufficient cause for one to do it. Importantly, though, it is no less a cause for that." 
Reasons and causes are compatible only by linguistic agreement. Significantly, Brassington continues:

6. It was the paint-drinker's desire to drink paint that caused him so to do; it does not follow automatically, though, that drinking paint is something that is forced upon him."

Only in this sentence does Brassington mention the use of force, without which psychiatry, as we know it, could not exist. The difference between amputating a patient's gangrenous limb with the patient's consent, and amputating a prisoner's healthy limb against his will as a religiouscriminal punishment is self evident. That forcible confinement in a so-called mental hospital is a type of incarceration is, in my view, also self evident. The defence of neither proposition requires a complicated philosophical underpinning. Robert Dixon, author of The Baumgarten Corruption, writes: "Locking people up', says Thomas Szasz, 'is a pivotal political act.' ... to lock people up is to punish and so to treat an act to which we apply a pseudo-medical label as if it were a crime".

7. "This approach would accommodate the claim that mental illness is a myth, but it would be able to go a step further also and claim that the same applies to mental 'health'."

This conclusion is part and parcel of my original argument, advanced in 1960 and $1961 .^{8}$

Summarising my thesis, Brassington writes: "This means that behaviour, the bread and butter of psychiatry, must no longer be seen in terms of illness". This is a correct restatement of my original intent. However, it lets psychiatry off the hook. Supposedly scientifically enlightened mental health professionals, and their political and journalistic followers, insist that the subject matter with which psychiatrists deal is neither the mind nor behaviour, but the brain:

Nancy C Andreasen, professor of psychiatry at the University of Iowa: "What we call 'mind' is the expression of the activity of the brain". ${ }^{\text {? }}$

Samuel B Guze, professor of psychiatry at Washington University in St. Louis: “The conclusion appears inescapable to me that what is called psychopathology is the manifestation of disordered processes in various brain systems ....". ${ }^{10}$

Lewis L Judd, director of the National Institute of Mental Health: "The brain is the organ of psychiatry". ${ }^{11}$

White House Fact Sheet on Myths and Facts about Mental Illness: "Research in the last decade proves that mental illnesses are diagnosable disorders of the brain". ${ }^{12}$
I could cite countless similar assertions by psychiatric and political authorities, and by jurists and journalists. Observing this scene, Dixon comments: "Mind is confused with matter if we treat moral and ideological acts as if they were 'proven organic lesions,' argues Szasz with great brilliance and purpose. Szasz ... unmasks a great absurdity, but has to watch the tide of opinion run the other way."13

I thank Brassington for his conclusion: "I have already said, I think that there is rather a lot going for Szasz's argument, and I agree, broadly, with the conclusion." Let me add the hope that he and others who share this opinion will apply themselves to the practical tasks implicit in rejecting the concept of mental illness-tasks that, in their scope and importance for a free society, invite comparison with the challenges American abolitionists faced at the beginning of the nineteenth century. ${ }^{14}$

\section{REFERENCES}

1 Szasz TS. The meaning of mind: language, morality, and neuroscience. New York: Praeger, 1996: ix-x.

2 Szasz TS. See reference 1: 1

3 Szasz TS. The myth of mental illness. American Psychologist 1960;15:113-18.

4 Szasz TS. Insanity: the idea and its consequences [1987]. Syracuse: Syracuse University Press, 1997; The meaning of mind: language, morality, and neuroscience. New York: Praeger, 1996; Pharmacracy: medicine and politics in America. Westport, CT: Praeger, 2001.

5 Weinberg S. Reductionism redux. New York Review of Books 1995 Oct 5: 40-1.

6 Szasz TS. See reference 1: 141

7 Dixon R. The Baumgarten corruption: from sense to nonsense in art and philosophy. London: Pluto Press, 1995: 153-4.

8 Szasz TS. The myth of mental illness: foundations of a theory of personal conduct. New York: Hoeber-Harper, 1961.

9 Andreasen NC. What is psychiatry? American Journal of Psychiatry 1997; 154:591-3

10 Guze SM. Biological psychiatry: Is there any other kind? Psychological Medicine 1989;19:315-23, emphasis in the original.

11 Judd LL. Quoted in: Emphasis on brain takes psychiatry on exciting path. Psychiatric Times 1988;23:5

12 White House press office. White House fact sheet on myths and facts about mental illness, June 5, 1999. Quoted in: Myths and facts about mental illness. New York Times 1999 Jun 7: internet edition.

13 Dixon R. The Baumgarten corruption: from sense to nonsense in art and philosophy. London: Pluto Press, 1995: 115

14 Szasz TS. Psychiatric slavery: when confinement and coercion masquerade as cure [1977]. Syracuse: Syracuse University Press, 1998, Insanity: the idea and its consequences [1987]. Syracuse: Syracuse University Press, 1997; Cruel compassion: the psychiatric control of society's unwanted [1994]. Syracuse: Syracuse University Press, 1998; Liberation by oppression: a comparative study of slavery and psychiatry. New Brunswick, NJ: Transaction Books, 2002; and Szasz TS, ed. The age of madness: a history of involuntary mental hospitalization. presented in selected texts. Garden City, NY: Doubleday Anchor, 1973. 